Abbreviated Key Title: Sch J Agric Vet Sci

ISSN 2348-8883 (Print) | ISSN 2348-1854 (Online)

Journal homepage: https://saspublishers.com

\title{
Evaluation of Safety, Immunogenicity and Potency of PPR Vaccine
}

Jaykumar Satav $^{1 *}$, KVN Rathnakar Reddi ${ }^{2}$, Gopu Akhila ${ }^{3}$, Dahiphale Hanumant ${ }^{4}$, TVS Rao ${ }^{5}$, GS Reddy ${ }^{6}$

\footnotetext{
${ }^{1}$ Sr. Research Scientist, Brilliant Bio Pharma Pvt. Limited, IDA, Pashamylaram, Hyderabad, Telangana, India

${ }^{2}$ Sr. Technical Officer, Brilliant Bio Pharma Pvt. Limited, IDA, Pashamylaram, Hyderabad, Telangana, India

${ }^{3}$ Trainee, Brilliant Bio Pharma Pvt. Limited, IDA, Pashamylaram, Hyderabad, Telangana, India

${ }^{4}$ Technical Officer, Brilliant Bio Pharma Pvt. Limited, IDA, Pashamylaram, Hyderabad, Telangana, India

${ }^{5}$ Senior Vice-President, Brilliant Bio Pharma Pvt. Limited, IDA, Pashamylaram, Hyderabad, Telangana, India

${ }^{6}$ Senior Vice-President, Brilliant Bio Pharma Pvt. Limited, IDA, Pashamylaram, Hyderabad, Telangana, India
}

DOI: $10.36347 /$ sjavs.2020.v07i12.001

| Received: 14.12.2020 | Accepted: 26.12.2020 | Published: 30.12.2020

*Corresponding author: Jaykumar Satav

Abstract

Original Research Article

Peste des Petits Ruminants (PPR) is one of the most economically important, highly contagious, fatal transboundary viral diseases of small ruminants affecting primarily the sheep and goats and caused by PPR virus (PPRV), a member in Morbillivirus genus of family Paramyxoviridae. As we know that prophylaxis using live attenuated vaccines is the primary choice of control measure as the immunity is long lasting. In this study, we evaluated safety, immunogenicity and potency of a live attenuated PPR vaccine manufactured by Brilliant Bio Pharma Private Limited in a freeze-dried form containing vaccine virus titer of $10^{3.5} \mathrm{CCID}_{50} /$ dose. The vaccine safety was tested in goats using 100 times the recommended field dose. In the safety trial, none of the vaccinated animals showed any deviation from physiological norms or fever. In the immunogenicity study, all the sheep and goats vaccinated by subcutaneous route developed virus-neutralizing antibody titer in the range of 1:8 to $1: 128$ at 21 days post-vaccination (dpv). While, in the potency study, all the vaccinated animals resisted challenge with virulent PPR virus on $21 \mathrm{dpv}$ and demonstrated full protection, while unvaccinated control sheep and goats showed characteristic clinical signs of PPR disease. Overall, the live attenuated PPR vaccine was found to be safe, immunogenic and potent as evident from safety, sero-conversion as well as challenge studies in sheep and goats.

Keywords: Peste des Petits Ruminants (PPR); prophylaxis; vaccines; safety; virus-neutralizing antibody titer; Potency.

Copyright $(\mathcal{C} 2020$ The Author(s): This is an open-access article distributed under the terms of the Creative Commons Attribution 4.0 International License (CC BY-NC 4.0) which permits unrestricted use, distribution, and reproduction in any medium for non-commercial use provided the original author and source are credited.

\section{INTRODUCTION}

Peste des Petits Ruminants (PPR) is one of the most economically important, highly contagious, fatal and transboundary viral diseases of small ruminants affecting primarily the sheep and goats. The PPR disease distributed worldwide and causes severe economic losses to poor farmers by affecting sheep and goats. The disease is characterized by high fever, necrotic stomatitis, ocular and nasal discharges, severe pneumonia, enteritis, diarrhoea, abortions followed by either death or recovery from the disease $[1,2]$. The causative agent of PPR disease is Peste des Petits Ruminants virus (PPRV) a member in Morbillivirus genus of family Paramyxoviridae [3]. PPRV is an enveloped RNA virus with a single stranded RNA genome of negative-sense [4]. There is a single serotype of PPRV, but genetically grouped into four distinct lineages (I, II, III, and IV) based on partial sequence analysis of Fusion (F) gene [5, 6]. In India the outbreaks primarily occur with the type IV lineages of PPRV. The
PPR disease causes high morbidity (up to 100\%) and mortality (up to $90 \%$ ) as well as a decline in productive performance results in devastating economic losses to the livestock industry globally [7, 8]. Mortality and morbidity of disease are high when occurring in naive sheep and goat population.

As a rough estimation, the economic impact of PPR causes \$1.45-\$2.1 billion (USD) loss in the world [9], and in India the economic losses estimated to be INR 1,800 million (US\$ 39 million) annually $[10,11]$.

Considering the economic, social and health impacts of PPR disease, the Food and Agriculture Organization of the United Nations (FAO) and the World Organization for Animal Health (OIE) jointly launched 'Global Strategy for the Control and Eradication of PPR' in 2015, aiming to eradicate PPR by 2030 [8]. In India, PPR was first reported in 1987 from Tamil Nadu (12) and presently PPR is enzootic in India and outbreaks were reported in sheep and goats 
regularly throughout the country incurring huge economic losses [13].

Presently Vero cell line based live attenuated PPR vaccines are used around the world of different PPRV lineage of either goat or sheep origin for prophylaxis of disease [14-17]. Vaccination is considered to be the most effective way to control PPR throughout the endemic regions. Considering this, Government of India has launched a PPR Control Programme (PPR-CP). The PPR Control Programme involving intensive vaccination of susceptible animals (Sheep and Goats) up to three subsequent generations to prevent the outbreak of PPR disease to reduce the economic losses of farmers and to eradicate the PPR disease from India similar to the eradication of Rinderpest disease.

Considering this overall scenario, Brilliant Bio Pharma Private Limited (BBPL) manufactured live attenuated PPR vaccine and the present study was undertaken to study the safety, immunogenicity and potency of live attenuated PPR vaccine made from PPR virus strain Sungri 96 obtained from Indian Veterinary Research Institute (IVRI), Mukteswar, Uttarakhand by propagating on Vero cells for the prevention and eradication of infection in sheep and goats.

\section{MATERIALS AND METHODS \\ Cells and Virus}

Vero cells (ATCC CCL-81) obtained from

Indian Veterinary Research Institute (IVRI), Mukteswar, Uttarakhand were used for propagation of PPR virus and testing of vaccine. The attenuated PPR virus strain Sungri 96 and virulent challenge PPR virus obtained from IVRI, were used in the study for manufacturing of PPR vaccine and challenge studies respectively.

\section{Preparation of the PPR Vaccine}

Vero cells suspended in Automod Minimum Essential Medium (MEM) containing 10\% FBS (Fetal Bovine Serum) were seeded into roller culture bottles $\left(1,700 \mathrm{~cm}^{2}\right)$ (Thermo Fisher scientific India Pvt. Ltd.) with a cell density of $0.3 \times 10^{6}$ cells $/ \mathrm{mL}$ and infected [at multiplicity of infection (m.o.i) of 0.01] with PPR vaccine virus and incubated at $37^{\circ} \mathrm{C}$. Confluent monolayer was observed after two days of cell seeding. Spent media of roller bottles with confluent monolayer was replaced by MEM with 2\% FBS. The roller bottles were observed for cytopathic effect (CPE) regularly under inverted microscope. More than 80-90 \% CPE was observed after 6-7 days post-infection (dpi) and virus was harvested from the roller bottles by freezing and thawing. The virus harvest was pooled and blended with freeze drying medium containing sucrose, lactalbumin hydrolysate and gelatine hydrolysate. Then the virus harvest was preserved at $-80^{\circ} \mathrm{C}$ deep freezer until lyophilized. After titration, suitable volume of virus harvest was filled in $2 \mathrm{ml}$ vials and freeze dried using Labocon freeze drier equivalent to 100 doses of vaccine. Normal saline $(0.85 \% \mathrm{NaCl})$ diluent was prepared and sterilised by autoclaving at $121^{\circ} \mathrm{C}$ for 30 minutes and then dispensed $100 \mathrm{~mL}$ in each sterile $100 \mathrm{~mL}$ diluent bottles.

\section{Virus Titration}

Virus titration was carried out in Vero cells to evaluate the titre of virus in the virus harvest and freeze-dried preparations. Serial ten-fold dilutions of virus suspension were made in maintenance medium and the virus was titrated in Vero cells seeded in all wells of 96-well microtiter plates using four replicates per dilution $(100 \mu \mathrm{L} /$ well). The plates were incubated in the presence of $5 \% \mathrm{CO}_{2}$ for 7 days and observed regularly under microscope for development of $\mathrm{CPE}$ during the incubation period. Virus infectivity titre was quantified by estimating the $50 \%$ cell culture infectivity dose $\left(\mathrm{CCID}_{50}\right)$ and end points were calculated as per Karber, 1931 [18] method.

\section{Animals}

Healthy sheep and goats of 6-12-month age of either sex were procured from market and maintained at BBPL farm for different studies. After arrival of animals at BBPL farm, all animals were de-wormed and screened for other infections by physical examination and quarantined for 15 days. All the healthy sheep and goats were screened for sero-negativity for PPRV antibodies by serum neutralization test (SNT). Seronegative sheep and goats for PPRV (Peste des petits ruminant's virus) antibodies were used for carrying out PPR vaccine safety, immunogenicity and potency studies in accordance with guidelines for care and handling of experimental animals, as per the committee for Purpose of Control and Supervision of Experiments on Animals (CPCSEA).

\section{Vaccination and Serum Sample Collection}

Sero-negative sheep and goats were used to evaluate PPR vaccine safety, immunogenicity and potency as per OIE guidelines for PPR vaccine testing. The freeze-dried PPR vaccine was reconstituted in the vaccine diluent (Normal saline) in such a way that to give $1 / 10^{\text {th }}$ dose $/ \mathrm{mL}, 1 \mathrm{dose} / \mathrm{mL}$ and 100 doses $/ \mathrm{mL}$. Different groups of sheep and goats were vaccinated as mentioned in Table 1. Blood samples were collected on ' 0 ' day and 21 days post-vaccination (dpv) for serum antibody estimation. Serum was separated from all the blood samples and heat inactivated at $56^{\circ} \mathrm{C}$ for 30 minutes and stored at $-20^{\circ} \mathrm{C}$ till further use.

\section{Safety of PPR vaccine}

The Vero cell adapted attenuated live PPR vaccine manufactured by BBPL was tested for safety in goats ( $\mathrm{n}=04$ Goats) by administering 100 times field dose $\left(10^{5} \mathrm{CCID}_{50} \mathrm{PPR}\right.$ virus titer) in $1 \mathrm{~mL}$ volume by subcutaneous route $(\mathrm{S} / \mathrm{C})$ in the neck region (Table-2) as per the standard guidelines of Indian Pharmacopoeia (IP) 2018 [19]. All the immunized animals were 
clinically monitored by regular observations and by recording daily rectal temperatures. Animals were critically observed for development of any specific signs or disease related symptoms of PPR following vaccination and rectal temperature was recorded daily up to 21 days post vaccination (dpv).

\section{Immunogenicity Study}

Serum antibody response to PPR vaccine in different groups of sheep and goats was estimated by SNT. Sheep and goats vaccinated with one tenth field dose and one field dose were observed for seroconversion (Table-1). SNT was carried out in Vero cells using method described by Golding, Rossiter, P. and O.I.E with minor modifications [20-22]. Briefly, Serum samples were serially diluted in doubling dilution (from 1:2 to 1:512) in a 96-well tissue culture plate and neutralised with $100 \mathrm{CCID}_{50}$ of PPR vaccine virus Sungri-96 strain and incubated for one hour in a $5 \%$ $\mathrm{CO}_{2}$ incubator at $37{ }^{\circ} \mathrm{C}$. Subsequently $100 \mu \mathrm{L}$ (micro litres) Vero cells were added $\left(0.2 \times 10^{6}\right.$ cells $\left./ \mathrm{mL}\right)$ per well in 96 well tissue culture plates (Nunc, Thermo scientific) and the plates were further incubated at
$37{ }^{\circ} \mathrm{C}$ in a $5 \% \mathrm{CO}_{2}$ incubator for 7 days. The plates were observed for CPE every alternative day. The cell, virus and serum controls were included for each plate. Final observation of PPRV specific CPE on the seventh day was recorded. The $\mathrm{SN}$ titres were calculated as the reciprocal of the highest dilution of serum that shows no CPE in $50 \%$ of wells. The sera were analysed for protective levels of antibodies in vaccinated animals. The SN titres $>8$ were considered as protective [21].

\section{Potency Test}

All sheep and goats vaccinated with $1 / 10^{\text {th }}$ and one field dose of vaccine along with other two seronegative control animals were experimentally challenged with $2.5 \mathrm{~mL}$ of $10 \%$ Splenic suspension of virulent challenge PPR Virus (with a minimum titre of $10^{3} \mathrm{LD}_{50} / \mathrm{mL}$ ) subcutaneously on $21 \mathrm{dpv}$. All animals were observed daily for 14 days post challenge for PPR specific clinical signs and body temperature was recorded daily. Vaccine passes the test if all vaccinated animals resist the challenge infection and all in-contact control animals develop specific signs of PPR disease (Table-3).

Table-1: Experimental design showing different groups of sheep and goats immunized with PPR vaccine for immunogenicity and potency study

\begin{tabular}{|l|l|l|l|}
\hline Sr. No. & Group (no. of animals) & Animal Number & Dose and route of vaccination \\
\hline 1 & A (n=08) & $\begin{array}{l}\text { Sheep-1,2,13,14 } \\
\text { Goat-7, 8,17,18 }\end{array}$ & 1 field dose $(1 \mathrm{~mL}), \mathrm{S} / \mathrm{C}$ \\
\hline 2 & B (n=08) & $\begin{array}{l}\text { Sheep-3,4, 15, 16 } \\
\text { Goat-9, } 10,19,20\end{array}$ & $1 / 10^{\text {th }}$ field dose $(1 \mathrm{~mL}), \mathrm{S} / \mathrm{C}$ \\
\hline 3 & C (n=04) & $\begin{array}{l}\text { Sheep-5,6 } \\
\text { Goat- } 11,12\end{array}$ & In-contact Control $(1 \mathrm{~mL}$ saline), S/C \\
\hline \multicolumn{3}{|l}{ S/C: Subcutaneous route }
\end{tabular}

\section{RESULTS}

The PPR virus grew very well in Vero cell line and demonstrated cytopathogenic effect (CPE) after 7 days of incubation and the titer of the harvested suspension was $\log _{10} 6 \mathrm{CCID}_{50} / \mathrm{mL}$. The vaccine batch produced from PPR virus was tested for sterility, purity and identity according to the standard guidelines (IP 2018). The infective titer per dose for PPR vaccine was found $\log _{10} 3.5 \mathrm{CCID}_{50} / \mathrm{mL}$. Safety, immunogenicity and potency of the vaccine were evaluated on sheep and goats as per the standard protocol and guidelines [19, 22].

\section{Safety}

In the safety study, the current PPR vaccine manufactured by BBPL did not show any reaction at the site of inoculation [23]. All vaccinated animals, even at 100 times field dose, remained healthy without any clinical sign of illness and rise in body temperature during the 21 days period following vaccination.

Table-2: Experimental design showing different groups used for evaluating safety of PPR vaccine in Goats (As per

\begin{tabular}{|c|c|c|c|c|c|c|}
\hline $\begin{array}{l}\text { Sr. } \\
\text { No. }\end{array}$ & $\begin{array}{l}\text { Group } \\
\text { (no. of } \\
\text { animals) }\end{array}$ & $\begin{array}{l}\text { Animal } \\
\text { Number }\end{array}$ & $\begin{array}{l}\text { Dose and } \\
\text { route of } \\
\text { vaccination }\end{array}$ & $\begin{array}{l}\text { Critical } \\
\text { sign } \\
\text { observed }\end{array}$ & $\begin{array}{l}\text { Rise in } \\
\text { body } \\
\text { temp. }\end{array}$ & PPR common signs and symptoms \\
\hline 1 & $\mathrm{~A}(\mathrm{n}=04)$ & $\begin{array}{l}\text { Goat-1, } \\
2,3,4\end{array}$ & $\begin{array}{lr}100 & \text { times } \\
\text { field dose }(1 \\
\mathrm{mL}) & \\
\mathrm{S} / \mathrm{C} & \end{array}$ & No & Normal & $\begin{array}{l}\text { PPR symptoms like, Rise in body } \\
\text { temperature, congested conjunctival } \\
\text { mucous membrane, ocular and nasal } \\
\text { discharges, stomatitis, necrotic lesions on } \\
\text { the oral mucosa, sores in the mouth, cough } \\
\text { and disturbed breathing and diarrhoea } \\
\text { were not observed. }\end{array}$ \\
\hline
\end{tabular}




\section{Immunogenicity}

All the sheep and goats vaccinated with $1 / 10^{\text {th }}$ field dose and 1 field dose of PPR vaccine through S/C route were bled and sera were tested by SNT to determine the neutralizing antibody titer on $21 \mathrm{dpv}$. The SNT results of the vaccinated sheep and goats on 21 $\mathrm{dpv}$ are presented in the Table-3. Overall, all vaccinated sheep and goats with 1 field dose and $1 / 10^{\text {th }}$ field dose showed very good SNT titers ranging from 1:8 to 1:128. All the vaccinated animals showed $>8 \mathrm{SN}$ titre. Thus, it is evident that the vaccine under study elicited protective immune response in animals $[19,21]$ when inoculated with $1 \mathrm{ml}$ of the vaccine containing 1 field dose and $1 / 10^{\text {th }}$ field dose of PPR virus (Table-3).

Table-3: Results of neutralizing PPR antibody response after vaccination of sheep and Goat by PPR vaccine

\begin{tabular}{|c|c|c|c|c|}
\hline \multirow[t]{2}{*}{ Group (no. of animals } & \multirow[t]{2}{*}{ Vaccinated Animals } & \multirow[t]{2}{*}{ Animal Number } & \multicolumn{2}{|c|}{ Days post vaccination (SNT titer) } \\
\hline & & & Day 0 & Day 21 \\
\hline \multirow[t]{8}{*}{$A(n=08)$} & \multirow[t]{4}{*}{ Sheep } & 1 & $<1: 2$ & $1: 64$ \\
\hline & & 2 & $<1: 2$ & $1: 64$ \\
\hline & & 13 & $<1: 2$ & $1: 128$ \\
\hline & & 14 & $<1: 2$ & $1: 128$ \\
\hline & \multirow[t]{4}{*}{ Goat } & 7 & $<1: 2$ & $1: 64$ \\
\hline & & 8 & $<1: 2$ & $1: 128$ \\
\hline & & 17 & $<1: 2$ & $1: 128$ \\
\hline & & 18 & $<1: 2$ & $1: 128$ \\
\hline \multirow[t]{8}{*}{$B(n=08)$} & \multirow[t]{4}{*}{ Sheep } & 3 & $<1: 2$ & $1: 64$ \\
\hline & & 4 & $<1: 2$ & $1: 128$ \\
\hline & & 15 & $<1: 2$ & $1: 128$ \\
\hline & & 16 & $<1: 2$ & $1: 128$ \\
\hline & \multirow[t]{4}{*}{ Goat } & 9 & $<1: 2$ & $1: 128$ \\
\hline & & 10 & $<1: 2$ & $1: 128$ \\
\hline & & 19 & $<1: 2$ & $1: 128$ \\
\hline & & 20 & $<1: 2$ & $1: 8$ \\
\hline \multirow[t]{4}{*}{$\mathrm{C}(\mathrm{n}=04)$} & \multirow[t]{2}{*}{ Sheep } & 5 & $<1: 2$ & $<1: 2$ \\
\hline & & 6 & $<1: 2$ & $<1: 2$ \\
\hline & \multirow[t]{2}{*}{ Goat } & 11 & $<1: 2$ & $<1: 2$ \\
\hline & & 12 & $<1: 2$ & $<1: 2$ \\
\hline
\end{tabular}

\section{Potency}

In the potency study, all the vaccinated and control sheep and goats were challenged with the virulent challenge PPR virus. The challenge studies were carried out on $21 \mathrm{dpv}$ with virulent challenge PPR virus developed and supplied by IVRI. The virulent challenge PPR virus was administered at the dose of $2.5 \mathrm{~mL}$ of $10 \%$ Splenic suspension to all vaccinated sheep and goats including in-contact control as per the guidelines of IP 2018 by s/c route and animals were observed for 14 days post challenge for development of any clinical signs of PPR disease. The challenge studies in sheep and goats confirmed the efficacy of live attenuated PPR vaccine in terms of $100 \%$ protection afforded to all vaccinated animals, however the control animals unable to resist the challenge infection and demonstrated disease with severe clinical signs of PPR infection such as rise in body temperature, congested conjunctival mucous membrane, ocular and nasal discharges, oral and lingual necrotic lesions typical of PPR (Table-4).

Table-4: Experimental design showing different groups of sheep and Goats used for evaluating potency of PPR vaccine

\begin{tabular}{|c|c|c|c|c|}
\hline $\begin{array}{l}\text { Sr. } \\
\text { No }\end{array}$ & $\begin{array}{l}\text { Group (no. of } \\
\text { animals) }\end{array}$ & Animal No & $\begin{array}{l}\text { Dose of challenge virus } \\
\text { (S/C) }\end{array}$ & $\begin{array}{l}\text { No. of animals protected/ } \\
\text { challenged }\end{array}$ \\
\hline 1 & $A(n=08)$ & $\begin{array}{l}\text { Sheep-1,2,13,14 } \\
\text { Goat- } 7,8,17,18\end{array}$ & \multirow[t]{3}{*}{$\begin{array}{l}2.5 \mathrm{~mL} \text { of } 10 \% \text { Splenic } \\
\text { suspension }\end{array}$} & $08 / 08$ \\
\hline 2 & $\mathrm{~B}(\mathrm{n}=08)$ & $\begin{array}{l}\text { Sheep-3,4, 15, } 16 \\
\text { Goat-9, } 10,19,20\end{array}$ & & $08 / 08$ \\
\hline 3 & $C(n=04)$ & $\begin{array}{l}\text { Sheep-5,6 } \\
\text { Goat-11, } 12\end{array}$ & & $0 / 2$ \\
\hline
\end{tabular}

\section{DISCUSSION}

In the present study, PPR virus was propagated on Vero cells, resulted in considerable titer which helps to produce good potent and safe vaccine. Also, in the present study the virulent challenge PPR virus splenic suspension was prepared and had a considerable titer in in-vivo models, which is demonstrated by disease induction in the control animals. This showed that the 
virulent challenge virus used in the present study was highly virulent and pathogenic for sheep and goats.

The PPR vaccine was tested for safety at 100 times field dose in goats and found safe (as per IP 2018). The vaccinated animals did not show any clinical signs of PPR disease and remained healthy till the end of observation period of $21 \mathrm{dpv}$. Earlier studies carried out by using the vaccine manufactured with Sungri 96 PPR virus strain demonstrated very good safety of vaccine at 100 times field dose as shown in the present study [24]. This clearly indicated that the PPR virus which was used for the preparation of vaccine was sufficiently attenuated and can be used as a vaccine at the field level. All the animals vaccinated with 1 field dose and $1 / 10^{\text {th }}$ field dose demonstrated satisfactory serum neutralization titers ranging from 1:8 to 1:128. Similar observations were reported in earlier studies [25, 23]. As reported by IP 2018 and O.I.E 2019, challenge study is the method of choice to assess the protection provided by PPR vaccines and the same was conducted in the present study. All vaccinated animals were protected without showing any clinical symptoms of disease, whereas the control animals succumbed to challenge and shown specific signs of PPR disease such as rise in body temperature congested conjunctival mucous membrane, ocular and nasal discharges, stomatitis, and necrotic lesions on the oral mucosa. Importantly, earlier published work on PPR Sungri 96 also demonstrate similar finding [23]. The earlier studies reported that the PPR live attenuated Sungri 96 strain vaccine was found safe, immunogenic, highly potent and single vaccination is sufficient to provide lifelong immunity in sheep and goats [25, 23, 26, 27].

\section{CONCLUSION}

The present study showed that the live attenuated PPR vaccine manufactured using Sungri 96 strain is safe, immunogenic and potent to protect vaccinated animals (Sheep and Goat) against the virulent challenge PPR virus. This suggests that the present PPR vaccine could be suitable for use under field conditions to prevent outbreaks of PPR disease in India.

\section{ACKNOWLEDGEMENTS}

The authors are thankful to the management of Brilliant Bio Pharma Private Limited, Hyderabad for providing necessary facilities to carry out the research work.

\section{REFERENCES}

1. Balamurugan V, Apsana, R, Raju, D.S.N., Abraham, S, Govindaraj G, Nagalingam M, Hemadri D, Veeregowda BM, Gajendragad MR, Rahman H. Epidemiological investigation of the peste des petitis ruminants outbreaks in Tumkur district, Karnataka, India. Journal of Pathology Research. 2014; 3(2):71-75.
2. Balamurugan V, Hemadri D, Gajendragad MR, Singh, RK, Rahman H. Diagnosis and control of peste des petits ruminants: a comprehensive review. Virus disease. 2014; 25(1): 39-56.

3. Rima B, Collins P, Easton A, Fouchier R, Kurath G, Lamb RA, Lee B, Maisner A, Rota P, Wang L. ICTV virus taxonomy profile: Pneumoviridae. Journal of General Virology. 2017; 98(12): 2912-2913.

4. Diallo A. Morbillivirus group: genome organisation and proteins. Veterinary microbiology. 1990; 23(1-4): 155-163.

5. Shaila MS, Shamaki D, Forsyth MA, Diallo A, Goatley L, Kitching RP, Barrett T. Geographic distribution and epidemiology of peste des petits ruminants viruses. Virus research. 1996; 43(2): 149-153.

6. Dhar P, Sreenivasa BP, Barrett T, Corteyn M, Singh RP, Bandyopadhyay SK. Recent epidemiology of peste des petits ruminants virus (PPRV). Veterinary microbiology. 2002; 88(2): 153-159.

7. Santhamani R, Singh RP, Njeumi F. Peste des petits ruminants diagnosis and diagnostic tools at a glance: perspectives on global control and eradication. Archives of virology. 2016; 161(11): 2953-2967.

8. FAO, O. Global strategy for the control and eradication of PPR. FAO and OIE. 2015.

9. Jones BA, Rich KM, Mariner JC, Anderson J, Jeggo M, Thevasagayam S, Cai Y, Peters AR, Roeder P. The economic impact of eradicating peste des petits ruminants: a benefit-cost analysis. PLoS One. 2016; 11(2): e0149982.

10. Venkataramanan R, Bandyopadhyay SK., Oberoi MS. Present status and strategies for the control of transboundary and other economically important animal diseases in India: a review. The Indian Journal of Animal Sciences. 2005; 75(4).

11. Singh RP. Strategic control of peste des petits ruminants. Veterinary and livestock sector: a blueprint for capacity building Sudhi. New Delhi: Satish Serial Publisher. 2012: 327-45.

12. Shaila MS, Purushothaman V, Bhavasar D, Venugopal K, Venkatesan RA. Peste des petits ruminants of sheep in India. Veterinary Record. 1989; 125(24): 602-602.

13. Singh RP, Saravanan P, Sreenivasa, BP, Singh RK, Bandyopadhyay SK. Prevalence and distribution of peste des petits ruminants virus infection in small ruminants in India. Rev Sci Tech. 2004; 23(3): 807-819.

14. Diallo A, Taylor WP, Lefevre PC, Provost A. Attenuation of a virulent PPR strain: potential homologous live vaccine. Revue d'Elevage et de Medecine Veterinaire des Pays Tropicaux. 1989.

15. Singh RK, Balamurugan V, Bhanuprakash V, Sen A, Saravanan P, Yadav MP. Possible control and eradication of peste des petits ruminants from 
India: technical aspects. Vet Ital. 2009; 45(3): 449-462.

16. Singh, R. P. Control strategies for peste des petits ruminants in small ruminants of India. Revue Scientifique et Technique-OIE. 2011; 30(3):879.

17. Singh RP, De UK, Pandey KD. Virological and antigenic characterization of two peste des petits ruminants (PPR) vaccine viruses of Indian origin. Comparative immunology, microbiology and infectious diseases. 2010; 33(4): 343-353.

18. Kärber G. Beitrag zur kollektiven Behandlung pharmakologischer Reihenversuche. NaunynSchmiedebergs Archiv für experimentelle pathologie und pharmakologie. 1931; 162(4): 480483.

19. Indian Pharmacopoeia "Published by The Indian Pharmacopoeia Commission, Govt. of India, Ministry of Health \& Family Welfare, Ghaziabad" 2018: 4356-4357.

20. Golding SM, Hedger RS, Talbot P. Radial immuno-diffusion and serum-neutralisation techniques for the assay of antibodies to swine vesicular disease. Research in veterinary science. 1976 Mar 1;20(2):142-7.

21. Rossiter PB, Jessett DM, Taylor WP. Microneutralisation systems for use with different strains of peste des petits ruminants virus and rinderpest virus. Tropical animal health and production. 1985 Jun 1;17(2):75-81.

22. OIE. Chapter 3.7.9. Peste des petits ruminants (infection with peste des petits ruminants virus: In
Manual of Diagnostic Tests and Vaccines for Terrestrial Animals; Office International des Epizooties: Paris, France. 2019.

23. Mahapatra M, Selvaraj M, Parida S. Comparison of Immunogenicity and Protective Efficacy of PPR Live Attenuated Vaccines (Nigeria 75/1 and Sungri 96) Administered by Intranasal and Subcutaneous Routes. Vaccines. 2020; 8(2):168.

24. Mathivanan B, Kilari S, Moulin V, Joosten P. Safety and Efficacy Profile of Ovilis@ PPR Vaccine in Goats and Sheep. Control of PPR disease: challenges and opportunities, proceedings of National Conference on PPR Disease. 2014; held in November 28-29.

25. Saravanan P, Sen A, Balamurugan V, Rajak KK, Bhanuprakash V, Palaniswami KS, Nachimuthu K, Thangavelu A, Dhinakarraj G, Hegde R, Singh RK. Comparative efficacy of peste des petits ruminants (PPR) vaccines. Biologicals. $2010 \mathrm{Jul}$ 1;38(4):479-85.

26. Parida S, Muniraju $M$, Mahapatra $M$, Muthuchelvan D, Buczkowski H, Banyard AC. Peste des petits ruminants. Veterinary microbiology. 2015 Dec 14;181(1-2):90-106.

27. Sen A, Saravanan P, Balamurugan V, Rajak KK, Sudhakar SB, Bhanuprakash V, Parida S, Singh RK. Vaccines against peste des petits ruminants virus. Expert review of vaccines. $2010 \mathrm{Jul}$ $1 ; 9(7): 785-96$. 